\title{
MINERAL EXCHANGES OF MAN
}

\section{iII. Mineral Metabolism During Treatment of a Case of Polycythemia Vera ${ }^{1}$}

By SAMUEL H. BASSETT, THOMAS KILLIP, AND WM. S. MCCANN

(From the Department of Medicine of the University of Rochester School of Medicine and Dentistry and the Medical Clinic of the Strong Memorial and Rochester Municipal Hospitals, Rochester, N. Y.)

(Received for publication June 27, 1931)

The hemolytic properties of phenylhydrazine and phenylhydrazine hydrochloride were first demonstrated by Hoppe-Seyler (16) in 1884. During the following thirty-four years the drug or its derivatives were used to some extent in the production of experimental anemia in animals, but it was not until 1918 that it achieved a place in human therapeusis through publication of experiments by Eppinger and Kloss (11) who employed it to bring about destruction of erythrocytes in polycythemia vera. Within recent years a number of metabolic studies have been reported by investigators employing phenylhydrazine or its derivatives in the treatment of this disease. These studies have dealt mainly with changes in the physical and chemical properties of the blood, with studies of renal and liver function and of nitrogen metabolism, before, during and after treatment with hemolytic agents. So far as we have been able to ascertain there have been no reports on the mineral exchanges during a period of blood destruction resulting from the administration of phenylhydrazine derivatives to patients with erythremia.

For the past three years we have had a patient with polycythemia vera under observation.

On two occasions he has been admitted to the hospital for study and on one of these admissions the exchanges of nitrogen, phosphorus, calcium, magnesium and iron were followed during blood destruction.

${ }^{1}$ Expenses of this investigation were defrayed by a grant from the Fluid Research Fund of the Rockefeller Foundation. 
The pertinent facts relative to his hospital admissions are summarized in the following case report.

\section{CASE REPORT}

F. D. No. 17059. A garage mechanic, 55 years old, was admitted July 28, 1928, complaining of severe pains in the lower back. The pain had been most acute for four days, lancinating in character, felt in both sides of the lumbar region radiating into the flanks. Motion was greatly limited and he was obliged to hold the back stiffly.

The past history and system review revealed that there had been a severe injury to the spine in an accident at the age of 11 . He had had typhoid fever at the age of 6 years. At 18 years he had a severe gonorrheal urethritis, and at 25 years a febrile polyarthritis presumed to be acute rheumatic fever. The patient's wife stated that at various times during the six years from 1922 to 1928 he had shown an extremely high color, a beet-red or crimson appearance of face, hands and feet, particularly in cold weather. In March, 1928, there was a marked eruption on the face with intense itching followed by scaliness which lasted for two months. The family history was interesting in view of the fact that the patient's father apparently suffered from a similar condition (19).

On examination, temperature, pulse and respirations were normal. The patient was restless with pain and constantly trying to assume a more comfortable posture. The skin and mucous membranes showed a deep cyanotic flush, the significance of which was not recognized at first. On repetition of the examination engorgement of vessels of the sof $t$ palate, of conjunctivae and sclerae and of the fundus oculi were noted, and also of the sublingual vessels. The examination of the heart and lungs showed no significant abnormalities. The blood pressure was $103 \mathrm{~mm}$. systolic, 80 $\mathrm{mm}$. diastolic. The tip of the spleen was distinctly palpable. The lumbar spine was completely rigid, and all attempts at motion induced excruciating pain. The deep lumbar muscles were rigid but not tender to palpation. There was no tenderness over the sacro-iliac regions, nor over the thoracic or cervical spines. The neurological examination was entirely normal. The first blood count revealed a polycythemia, red blood cells 7.3 millions, hemoglobin 140 per cent (21 grams per $100 \mathrm{cc}$.), leucocytes 14,300 . The cell volume determined by means of the hematocrit was 71 per cent.

The urine contained considerable albumin and many hyaline casts. There were no other urinary abnormalities. Roentgen examination of the lumbar spine showed extensive hypertrophic changes of a degenerative arthritis. The lungs showed on the film a diffuse peribronchial feathering resembling that seen in prolonged chronic passive congestion of the lungs. The Wassermann reaction of the blood was negative. Blood chemical examination showed an elevation of the nonprotein nitrogen, $50 \mathrm{mgm}$. per $100 \mathrm{cc}$., the 
uric acid $5.7 \mathrm{mgm}$.; creatine $3.2 \mathrm{mgm}$.; blood sugar $95 \mathrm{mgm}$. per $100 \mathrm{cc}$. The $\mathrm{CO}_{2}$ combining power was 57 volumes per cent. The blood calcium was $11.7 \mathrm{mgm}$. per $100 \mathrm{cc}$. The plasma contained no excess of bilirubin. The serum proteins were as follows: albumin 5.07 per cent, globulin 1.5 per cent, total 6.57 per cent.

The phenolsulphonephthalein excretion was 55 per cent in two hours. Two tests of the basal metabolic rate revealed it to be normal, minus 2.5 and minus 4.5 per cent of average normal. The patient was given treatment by diathermy to the back with rapid improvement in comfort. The erythemia was treated with phenylhydrazine hydrochloride, of which 2.4 grams were given in nine days. Blood destruction did not become apparent until 6 days after the drug was discontinued, when jaundice was noted, the urine became high colored, the blood counts and hemoglobin began to decrease, and leucocytosis increased. The blood count reached a minimum 27 days after the phenylhydrazine was discontinued, at which time the red cell count was 3.2 millions and thereafter it slowly rose again. At the height of the blood destruction the urine gave a positive reaction to guaiac. Subsequently the albuminuria disappeared, and bile pigments diminished and the urine became nearly normal.

The patient was readmitted on November 19, 1928, for a second course of treatment by blood destruction with a hydrazine derivative. At this time he was admitted to the metabolism unit for a study of the mineral metabolism during blood destruction.

\section{METHOD}

Blood chemistry. Hemoglobin was determined by Sahli's method (100 per cent hemoglobin taken as 15 grams hemoglobin per $100 \mathrm{cc}$. of whole blood); nonprotein nitrogen by the method of Folin and Wu (12); sugar and uric acid by Benedict's methods (6); carbon dioxide combining power of the plasma by the method of Van Slyke and Neill (25); serum calcium by Clark and Collip's (8) modification of the Tisdall method; serum proteins by the method of $\mathrm{Wu}$ and Ling (26); icterus index by the method of Cutten, Emerson and Woodruff (9); total blood volume, cell volume, and plasma volume by the use of "brilliant vital red" as described by Hooper, et al. (15).

Mineral exchanges. The methods employed for the estimation of the exchanges of nitrogen, phosphorus, calcium, magnesium, and iron were the same as reported in a previous publication (4) with the following exception: Actual analyses of the diets given the patient were not made. These diets were, however, very similar in composition to sample diets previously analyzed in our laboratory. An empirical correction has therefore been introduced for the calculation of the nitrogen and calcium intake values. These values have been reduced approximately 6 per cent and 15 per cent respectively below the intake levels as obtained by calculation from tables pub- 
lished by Rose (20). In the case of phosphorus, magnesium, and iron, the calculated values have been found to approximate quite closely the values determined by actual analysis and have been used without correction to estimate the intake.

\section{DISCUSSION}

The results of the study of mineral exchanges have been recorded in the Tables II and III. Hemoglobin determinations, icterus index and blood counts during the period of observation are shown graphically in Chart 1, and average values for hemoglobin, erythrocytes, and leucocytes together with blood volume determinations are recorded in Table I.

TABLE I

Changes in hemoglobin, red blood cells, leucocytes and blood volume

\begin{tabular}{|c|c|c|c|c|c|c|c|c|}
\hline \multirow{2}{*}{ Period date } & \multicolumn{3}{|c|}{ Blood counts } & \multicolumn{3}{|c|}{ Blood volume } & \multirow{2}{*}{$\begin{array}{c}\text { Esti- } \\
\text { mated } \\
\text { circulat- } \\
\text { ing hemo- } \\
\text { globin }\end{array}$} & \multirow{2}{*}{ Medication } \\
\hline & $\begin{array}{l}\text { Hemo- } \\
\text { globin }\end{array}$ & $\begin{array}{l}\text { Red } \\
\text { blood } \\
\text { cells }\end{array}$ & $\begin{array}{l}\text { White } \\
\text { blood } \\
\text { cells }\end{array}$ & $\begin{array}{l}\text { Plasma } \\
\text { volume }\end{array}$ & $\begin{array}{c}\text { Cell } \\
\text { volume }\end{array}$ & $\begin{array}{c}\text { Total } \\
\text { blood } \\
\text { volume }\end{array}$ & & \\
\hline $\begin{array}{l}\text { November } 20 \text { to } \\
27 \text { I } \\
8 \text { days }\end{array}$ & $\begin{array}{c}\text { per cent } \\
141\end{array}$ & $\begin{array}{c}\text { millions } \\
6.41\end{array}$ & $\begin{array}{c}\text { thousands } \\
15.9\end{array}$ & $c c$. & $c c$ & $c c$. & grams & None \\
\hline $\begin{array}{c}\text { November } 27 \text { to } \\
\text { Decenber } 5 \text { II } \\
8 \text { days }\end{array}$ & 151 & 6.88 & 18.85 & & & & & $\begin{array}{l}\text { Acetylphe- } \\
\text { nylhydra- } \\
\text { zine } \\
2.1 \text { grams }\end{array}$ \\
\hline $\begin{array}{c}\text { December } 6 \text { to } 14 \\
\text { III } \\
9 \text { days }\end{array}$ & 128 & 5.84 & 22.06 & & & & & $\begin{array}{l}\text { Acetylphe- } \\
\text { nylhydra- } \\
\text { zine } \\
0.8 \text { gram }\end{array}$ \\
\hline $\begin{array}{c}\text { December } 15 \text { to } \\
28 \text { IV } \\
14 \text { days }\end{array}$ & 91 & 3.86 & 27.71 & 3420 & 2140 & 5560 & 760 & None \\
\hline
\end{tabular}

Figures given for hemoglobin, erythrocytes and leucocytes are average values of daily determinations made throughout each period.

The agent used for blood destruction while the patient was in the metabolism unit was acetylphenylhydrazine. The net results of the 
administration of 2.9 grams of the drug compared favorably with those obtained during the previous period of treatment with phenylhydrazine hydrochloride (see case report). The total blood volume decreased from $7,790 \mathrm{cc}$. to $5,560 \mathrm{cc}$., the cell volume decreased from $5,330 \mathrm{cc}$. to $2,140 \mathrm{cc}$., a decrease of $3,190 \mathrm{cc}$. of cells; and the plasma volume increased by $960 \mathrm{cc}$. or from 2,460 to $3,420 \mathrm{cc}$. Coincident with the changes in blood volume there was a decrease in hemoglobin from 141 per cent to 91 per cent and a fall in the erythrocyte count from 6.4 million to 3.8 million per $\mathrm{cmm}$. The reductions in total blood volume,

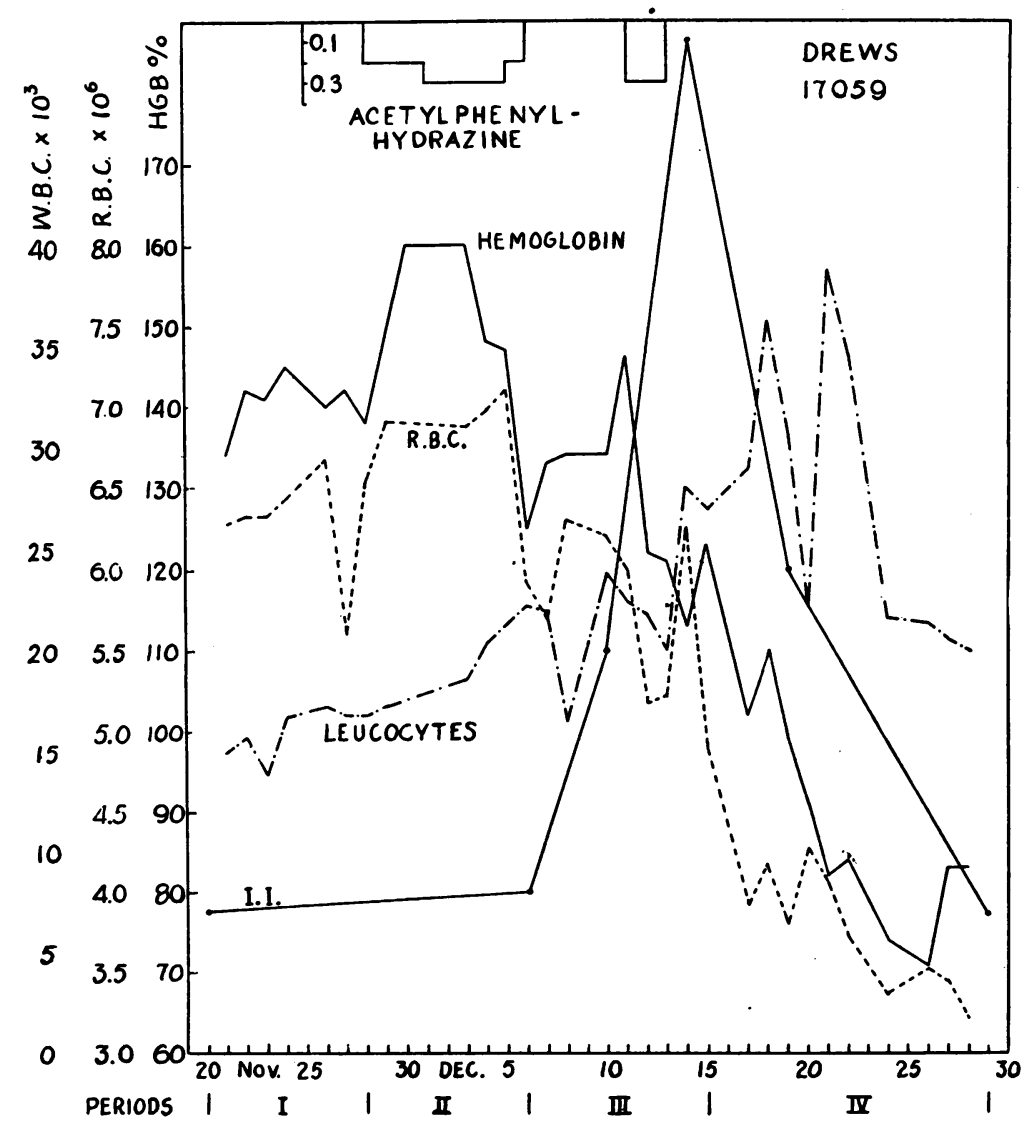

Chart 1. Hemoglobin, Erythrocytes, Leucocytes and Icterus Index (I. I.)

Units in scale on left refer to icterus index in units as well as to leucocytes in thousands. 
cell volume, hemoglobin and erythrocyte count are in accord with the studies of Brown and Giffin (7) and of Huffman (17).

Inspection of Chart 1 shows the rather pronounced delay in the onset of definite blood destruction following the administration of moderate daily doses of the drug. Long (18) has considered this point and suggested giving small doses, 0.1 gram daily until a total of 1 gram has been taken, and then waiting three days to see whether the effect has become cumulative. Giffin and Conner (13) have called attention to the fact that small daily doses of phenylhydrazine hydrochloride totaling not more than 3.5 gramis are usually effective as an initial course of treatment. Experience with our patient is in accord with these opinions and also suggests that in certain individuals it may be desirable to wait as long as a week following a course of phenylhydrazine in order to ascertain whether the hemolytic agent will take effect.

Elevation of the serum bilirubin during the period of active blood destruction has been said to occur quite consistently and jaundice is not uncommon (Harrop (14)). Determinations of the icterus index on patient F.D. showed it to be markedly increased with the onset of blood destruction. Distinct jaundice was present at the time maximum values for icterus index were obtained and the urine was deeply pigmented throughout the period of bilirubinemia.

Iron metabolism. A consideration of the iron metabolism in connection with blood destruction in this disease is of interest. The remarkable ability of the body to conserve its iron supply is well known. Lichtwitz (quoted by Thannhauser (23)) has estimated that about 12.5 grams of hemoglobin are broken down daily in the body and converted into bile pigment. The amount of iron liberated by this destruction of hemoglobin corresponds to about $\mathbf{4 2} \mathrm{mgm}$. of $\mathrm{Fe}$, a quantity five or six times greater than the daily iron excretion of a man during starvation. Furthermore, it has been shown that even a proportionately much greater destruction of hemoglobin in dogs caused by the administration of hemolytic agents results in no appreciable loss of body iron (Samuely (21); Dubin and Pearce (10)). Reasoning from analogy one would be led to suppose that the treatment of human polycythemia with phenylhydrazine derivatives (which is essentially the same as the production of an experimental anemia in animals with hemolytic agents) would not result in any considerable increase in iron excretion. 
This in fact appears to be the case. Patient F. D. remained essentially in iron balance during the first 16 days of the experiment with normal amounts of iron excreted in urine and feces. In the following 9 days there was a marked increase in the amount of iron excreted in

TABLE II

Iron metabolism

\begin{tabular}{|c|c|c|c|c|c|}
\hline Period date & $\begin{array}{l}\text { Iron in } \\
\text { food }\end{array}$ & $\begin{array}{c}\text { Iron } \\
\text { excreted }\end{array}$ & $\begin{array}{c}\text { Iron } \\
\text { balance }\end{array}$ & Medication & Remarks \\
\hline $\begin{array}{c}\text { November } 20 \text { to } 27 \\
\text { I }\end{array}$ & $m g m$. & \begin{tabular}{l}
\multicolumn{2}{c}{$m g m}$. \\
Urine 4.4 \\
Feces 111.8
\end{tabular} & $m g m$. & & \\
\hline 8 days & 106.3 & Total 116.2 & -9.9 & None & \\
\hline \multirow{2}{*}{$\begin{array}{l}\text { November } 28 \text { to } \\
\text { December } 5 \text { II } \\
8 \text { days }\end{array}$} & & $\begin{array}{ll}\text { Urine } & 11.9 \\
\text { Feces } & 84.8\end{array}$ & & $\begin{array}{l}\text { Acetylphenyl- } \\
\text { hydrazine }\end{array}$ & \\
\hline & 100.4 & Total 96.7 & +3.7 & 2.1 grams & \\
\hline $\begin{array}{c}\text { December } 6 \text { to } 14 \\
\text { III }\end{array}$ & & $\begin{array}{ll}\text { Urine } & 38.4 \\
\text { Feces } & 54.2\end{array}$ & & $\begin{array}{l}\text { Acetylphenyl- } \\
\text { hydrazine }\end{array}$ & \multirow{4}{*}{$\begin{array}{l}\text { Reduction in } \\
\text { circulating } \\
\text { hemoglobin } \\
\text { approximately } \\
900 \text { grams } \\
\text { equals } 3 \\
\text { grams Fe }\end{array}$} \\
\hline 9 days & 118.3 & Total 92.6 & +25.7 & 0.8 gram & \\
\hline \multirow{2}{*}{$\begin{array}{c}\text { December } 15 \text { to } 28 \\
\text { IV } \\
14 \text { days }\end{array}$} & \multirow[b]{2}{*}{178.9} & $\begin{array}{ll}\text { Urine } & 25.3 \\
\text { Feces } & 66.2\end{array}$ & \multirow[b]{2}{*}{+87.4} & \multirow[b]{2}{*}{ None } & \\
\hline & & Total 91.5 & & & \\
\hline 39 days & 503.9 & 397.0 & +106.9 & & \\
\hline
\end{tabular}

the urine which is probably to be accounted for on the basis of hemoglobinuria occurring at the time of maximum blood destruction. Coinciding with the increased elimination of iron in the urine there was a decrease in the quantity of iron found in the feces which more than compensated for urinary loss. Whether or not this diminished fecal excretion was more than a matter of chance is not known. However, during the final period of 14 days the same general relationship between urine and fecal iron excretion was noted, although the total urinary iron for this period was less than for the preceding 9 days. During the final 23 days of the experiment which included the entire period of blood 
destruction, there was a positive iron balance of $113 \mathrm{mgm}$. From data furnished by hemoglobin and blood volume determinations it has been estimated that during these 23 days the circulating hemoglobin was decreased by approximately 900 grams (see Table I) and that 3 grams of iron must theoretically have been available for excretion or deposition in organs and tissues. The destruction of hemoglobin leading to this enormous increase in endogenous iron metabolism would actually seem to have provided a stimulus which caused retention of food iron as evidenced by the positive iron balance. The objection might now well be raised that since the iron balance was not followed during the subsequent period of blood regeneration one does not know that iron excretion was not delayed and that excretion of the iron liberated from hemoglobin did not eventually occur. Such a delayed iron excretion is not in accord with experimental evidence. Dubin and Pearce (10) followed the iron eliminated in the urine and feces of dogs kept on a constant diet, and noted no increase in the total iron excreted when anemia was produced by the administration of toluylendiamine nor in the subsequent periods when the dogs were recovering from anemia. Moreover there is some evidence (2) to show that dogs kept anemic by daily administration of phenylhydrazine hydrochloride for a period of 5 months have increased deposits of iron in the liver and spleen when killed subsequent to recovery from the anemia. These facts are in accord with our iron balance data in the human subject.

\section{Nitrogen and phosphorus metabolism}

Huffman (17) has shown that patients with erythremia on a fixed diet showed negative nitrogen balances during the period of erythrocyte disintegration brought about by the administration of phenylhydrazine. The nitrogen balance in patient F. D. (Chart 2) was negative throughout the period of observation although his activity was minimal and he was receiving a protein intake of about 61 grams per diem with a daily caloric value for his diet of about 2400 calories. (Basal requirement 1755 calories.) The daily nitrogen excretion indicates that maximum nitrogen loss occurred during the periods when maximum values for icterus index were obtained or when blood destruction was most marked (Charts 1 and 2). It seems reasonable to assume that a large portion of the negative nitrogen balance was de- 
rived from red cell disintegration. If this is true and the reduction in quantity of erythrocytes as estimated by blood volume determinations is approximately correct, then a negative nitrogen balance of about 198 grams resulting from red cell destruction might have been expected.

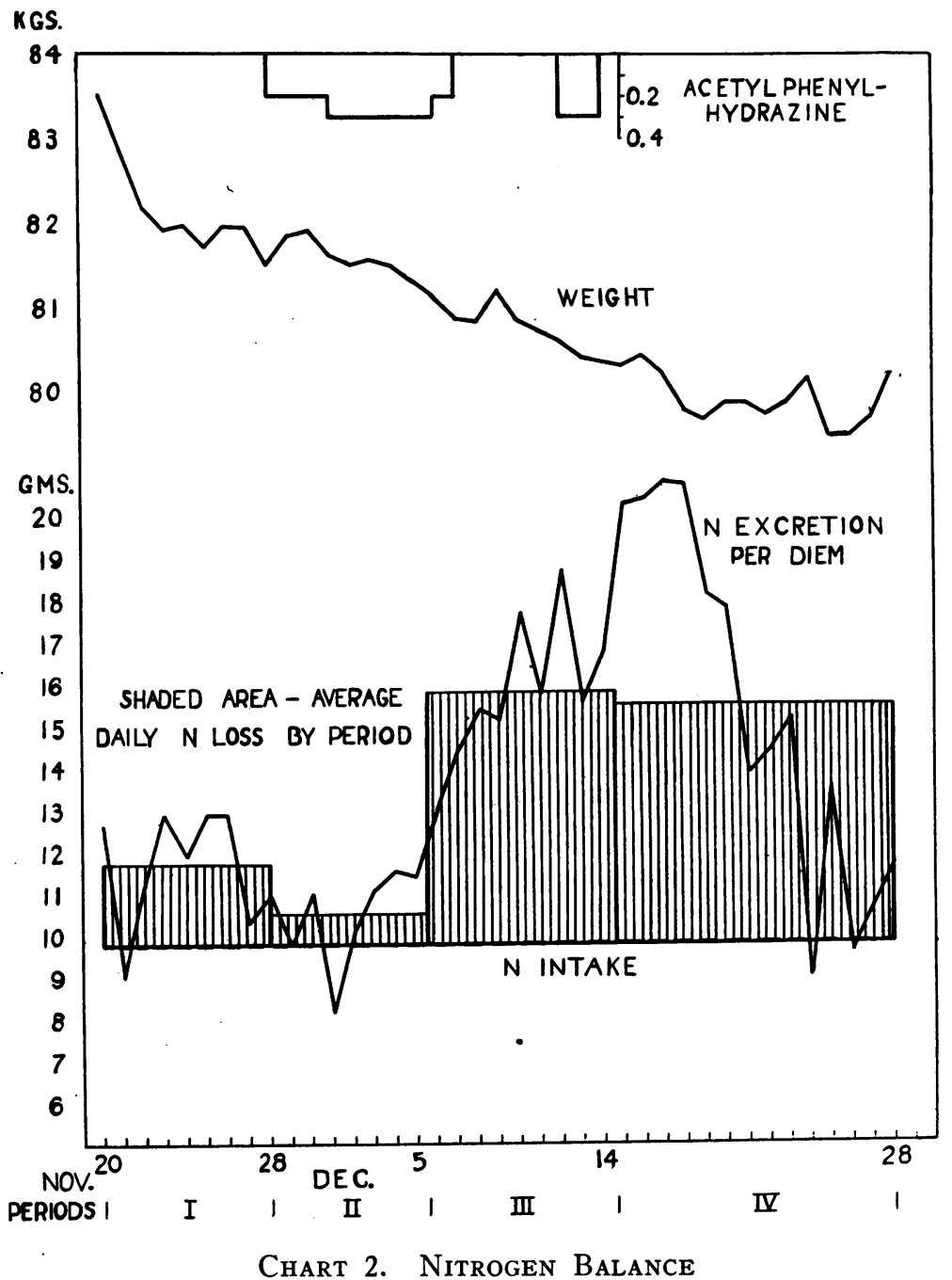

Equilibrium was practically established during the second period. Comparison with Chart 1 shows that the marked negative nitrogen balance coincides with the rapid decrease in hemoglobin and erythrocytes and with the maximum values for icterus index. 
The observed negative nitrogen balance (see Table III-Periods III and IV) was, however, only about 134 grams. It would seem then that some nitrogen containing fraction or fractions of the disintegrated erythrocytes, were retained perhaps to be reutilized in the formation of new hemoglobin.

Examination of the data pertaining to phosphorus metabolism (Table III) shows that during the first 16 days of the experiment the patient remained practically in phosphorus balance although there was a loss of both nitrogen and calcium. A distinctly negative phosphorus balance was noted only in Period III. Since destruction of blood occurred not only in this period but also during a considerable part of the subsequent one, a more complete picture of phosphorus metabolism at this time is obtained by considering the final 23 days of observation as a single period. With a loss of 134 grams of nitrogen there was retention of 1.31 gram of phosphorus. The small amount of calcium (1.68 gram) retained simultaneously could have accounted for a retention of 0.87 gram of phosphorus deposited as tertiary calcium phosphate in bone. The positive phosphorus balance at first appears surprising in view of the relationship between "theoretical" and actual phosphorus balances shown by Aub and his collaborators (3) (1). The assumption has already been made that most, if not all, of the negative nitrogen balance resulted from red blood cell disintegration; this being the case, the ratio of nitrogen to phosphorus in the excreta would be about $80: 1$ instead of $17: 1$ as might have been expected had the nitrogen excretion been dependent upon the catabolism of other body tissue (exclusive of bone). Such a ratio must necessarily materially decrease the excretion of phosphorus associated with nitrogen. The expected negative phosphorus balance therefore becomes so small as to be within the limit of error of the method used in calculating the balances. Finally, as in the case of nitrogen, it is possible that some of the phosphorus-containing fractions of the erythrocytes escaped excretion and remained to take part in the regenerative process during the subsequent period of recovery from acetylphenylhydrazine intoxication. Aside from speculation of this sort, it is evident that phosphorus was not lost from the body in appreciable amounts during the period of erythrocyte disintegration. 
SAMUEL H. BASSETT, THOMAS KILLIP AND WM. S. MCCANN

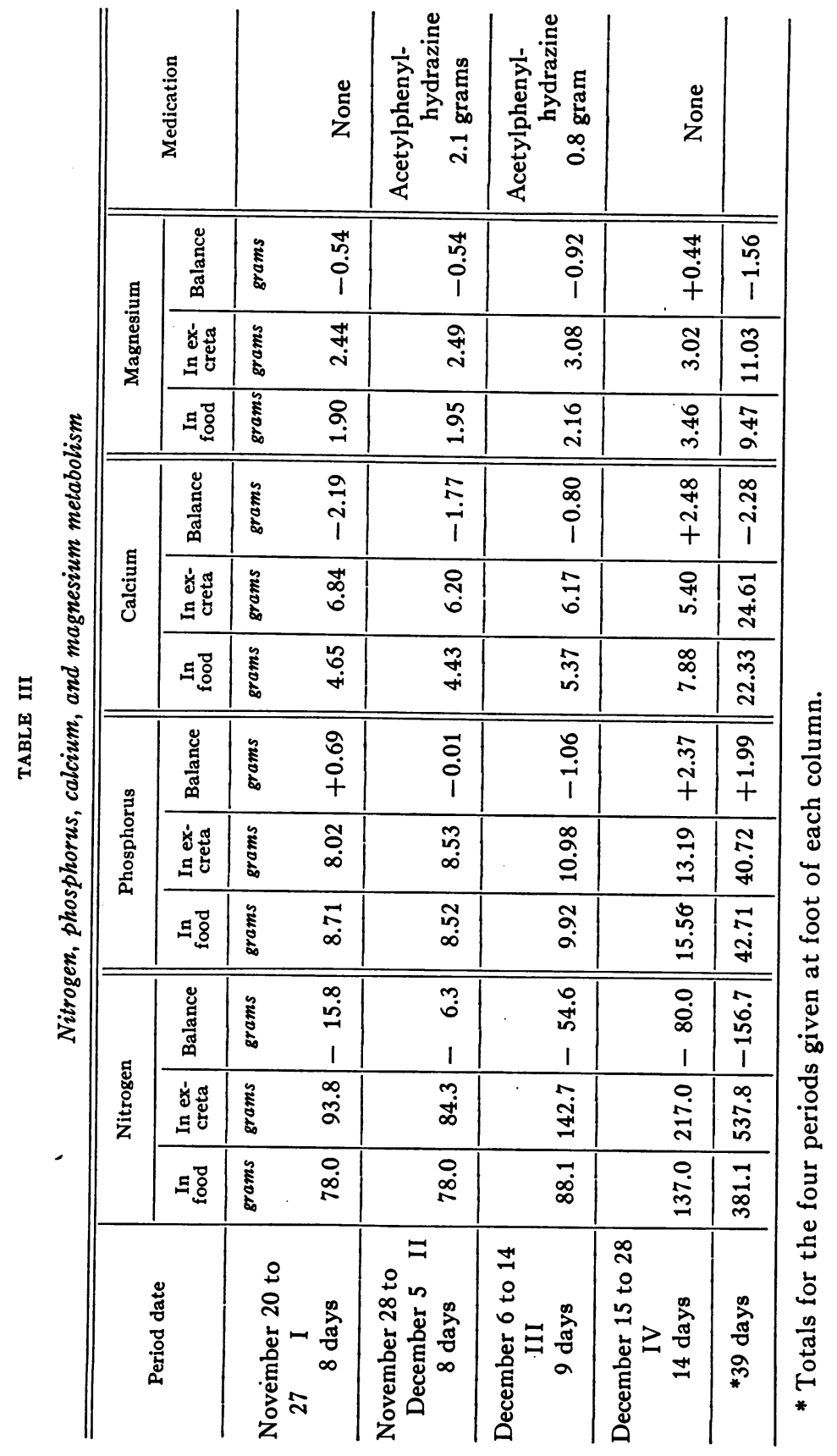




\section{Calcium and magnesium metabolism}

Calcium. The average daily calcium intake for F. D. amounted to about 0.57 gram. Daily variation from this average figure was small, so that although the individual balance periods were of different lengths, the calcium intake per period calculated on a per diem basis was almost identical. Sherman (22) has shown that the minimum of actual need for a man of $70 \mathrm{kgm}$. is about 0.45 gram Ca per diem. For a man of approximately $80 \mathrm{kgm}$. (the weight of F. D.) this would be about 0.51 gram $\mathrm{Ca}$ a day, a quantity which very closely approaches the actual amount fed. From this fact alone it might be expected that F. D. would show both positive and negative balances, which would tend to equalize each other if observations were continued for a sufficient length of time, assuming of course that the effect of such other factors as disease, medication, acid-base values of diet, activity, vitamins, etc., supposed to influence calcium metabolism could be excluded. It will be noted (Table III) that negative calcium balances were obtained during the first three periods and that these negative balances became progressively less until in the final period calcium was retained. The net result was a loss of 2.28 grams of calcium in 39 days. Nothing abnormal was noted in the partition of excreted calcium between urine and stool. The daily urinary calcium excretion was greatest (132 mgm.) in Period III which marks the onset of blood destruction, and least (73 mgm.) in Period IV at the time calcium was being retained. Such variations are probably within normal limits and of no particular significance.

Two determinations of serum calcium made prior to the onset of blood destruction gave values of 11.5 and $11.9 \mathrm{mgm}$. per $100 \mathrm{cc}$. which are within normal limits for the method used and are in agreement with the findings of Benedict and Turner (5).

Magnesium balances paralleled the calcium balances quite closely and it would appear that whatever factors were operative in causing a loss of calcium during the first three periods may also have resulted in a loss of magnesium. The minimal magnesium requirement sufficient to maintain a man of average size in balance does not appear to be known. It is readily conceivable however that it is subject to considerable individual variations, as is the case with other minerals, and may be influenced by many factors, not least of which may be the absolute level of intake in the diet. 
The average daily magnesium intake as found by Sherman (22) in a study of 150 American dietaries was 0.34 gram per man per day and per 3000 calories. Studies made by Carl Tigerstedt (24) in Finland indicate a much higher daily magnesium intake by men in that country ( 0.863 gram per day and per 2500 to 3500 calories). The subject of this investigation received a daily average of 0.243 gram of magnesium in his diet. Magnesium losses during the first two periods were almost identical, 0.542 and 0.543 gram respectively. During the third period the loss amounted to 0.919 gram and in the final period 0.437 gram of magnesium was retained. The loss of magnesium during the entire period of observation was considerably greater in proportion to intake than that for calcium, amounting to 16.5 per cent of the total intake, while that for calcium amounted to 10.2 per cent of the total intake.

Considering the length of time the patient was under observation (39 days) and in view of the fact that retention of calcium and magnesium occurred during the final period, it is probable that the net losses of 2.28 grams of calcium and 1.56 gram of magnesium during the four periods, were not associated with any marked disturbance of the factors governing the metabolism of these two elements.

It is rather interesting to note that positive balances for all the elements studied (except nitrogen) were obtained only in the final period. We are inclined to regard this phenomenon as an expression of anabolic activity on the part of the body tissues since the effect of acetylphenylhydrazine had apparently ceased prior to the end of this period. It is realized however, that one must exercise extreme caution in drawing any conclusions from such limited experience.

SUMMARY

1. The administration of 2.9 grams of acetylphenylhydrazine in doses of 0.2 to 0.3 gram per day to a patient with polycythemia vera resulted in marked reduction of total blood volume, cell volume, hemoglobin and erythrocyte count. An increase in the leucocyte count, icterus index and plasma volume occurred during blood destruction.

2. The large increase in endogenous iron metabolism accompanying erythrocyte disintegration did not result in loss of body iron. Hemoglobinuria is believed to have accounted for increased iron excretion in the urine during blood destruction. 
3. Marked loss of nitrogen took place during the periods of blood destruction but the loss did not seem of sufficient magnitude to account for all the nitrogen contained in the destroyed erythrocytes.

4. Significant changes in the metabolism of phosphorus, calcium and magnesium were not demonstrated.

\section{BIBLIOGRAPHY}

1. Albright, Fuller, Bauer, Walter, Ropes, Marion, and Aub, Joseph C., J. Clin. Invest., 1929, vii, 139. Studies of Calcium and Phosphorus Metabolism. IV. The Effect of the Parathyroid Hormone.

2. Allen, E. V., and Barker, N. W., Ann. Int. Med., 1928, i, 683. Experiments with Phenylhydrazine. III. Pathologic Anatomy.

3. Aub, J. C., Bauer, Walter, Heath, Clark, and Ropes, Marion, J. Clin. Invest., 1929, vii, 97. Studies of Calcium and Phosphorus Metabolism. III. The Effects of the Thyroid Hormone and Thyroid Disease.

4. Bassett, S. H., Elden, C. A., and McCann, W. S., J. Nutrition, 1931, iv, 235. The Mineral Exchanges of Man. I. Organization of Metabolism Ward and Analytical Methods.

5. Benedict, E. M., and Turner, K. B., J. Clin. Invest., 1930, ix, 263. The Serum Calcium in Polycythemia Vera.

6. Benedict, Stanley R., J. Biol. Chem., 1922, li, 187. The Determination of Uric Acid in Blood. J. Biol. Chem., 1926, lxviii, 759. The Estimation of Sugar in Blood and Normal Urine.

7. Brown, G. E., and Giffin, H. Z., Arch. Int. Med., 1926, xxxviii, 321. The Treatment of Polycythemia Vera (Erythremia) with Phenylhydrazine.

8. Clark, E. P., and Collip, J. B., J. Biol. Chem., 1925, 1xiii, 461. A Study of the Tisdall Method for the Determination of Blood Serum Calcium with a Suggested Modification.

9. Cutten, Claire, Emerson, E. E., and Woodruff, W., Arch. Int. Med., 1928, xli, 428. The Icterus Index. Spectrophotometric and Quantitative Studies.

10. Dubin, Harry, and Pearce, R. M., J. Exp. Med., 1917, xxv, 675. The Elimination of Iron and its Distribution in the Liver and Spleen in Experimental Anemia.

11. Eppinger, H., and Kloss, K., Therap. Monatsschr., 1918, xxxii, 322. Zur Therapie der Polyzythämie.

12. Folin, Otto, and Wu, Hsien, J. Biol. Chem., 1919, xxxviii, 81. A System of Blood Analysis.

13. Giffin, Herbert Z., and Conner, H. M., J. Am. Med. Assoc., 1929, xcii, 1505. The Untoward Effects of Treatment by Phenylhydrazine Hydrochloride. 
14. Harrop, George A., Jr., Medicine, 1928, vii, 291. Polycythemia.

15. Hooper, C. W., Smith, H. P., Belt, A. E., and Whipple, G. H., Am. J. Physiol., 1920, li, 205. Blood Volume Studies. I. Experimental Control of a Dye Blood Volume Method.

16. Hoppe, Seyler G., Ztschr. f. Physiol. Chem., 1884-85, ix, 34 . Ueber die Wirkung des Phenylhydrazins auf den Organismus.

17. Huffman, L. D., Arch. Int. Med., 1927, xxxix, 656. Metabolic Studies in the Treatment of Polycythemia Vera with Phenylhydrazine.

18. Long, Perrin H., J. Clin. Invest., 1925, ii, 315. Effect of Phenylhydrazine Derivatives in the Treatment of Polycythemia.

19. Owen, Trevor, Bull. Johns Hop. Hosp., 1924, xxxv, 258. A Case of Polycythemia Vera with Special Reference to the Familial Features and Treatment with Phenylhydrazine.

20. Rose, M. S., A Manual of Dietetics. The Macmillan Company, New York, 1927.

21 Samuely, F., Deutsches Arch. f. klin. Med., 1906-07, lxxxix, 220. Stoffwechseluntersuchungen bei experimenteller Anämie.

22. Sherman, H. C., Chemistry of Food and Nutrition. The Macmillan Company, New York, 1926, 3rd ed.

23. Thannhauser, S. J., Lehrbuch des Stoff wechsel und Stoffwechselkrankheiten. J. F. Bergmann, Munich, 1929.

24. Tigerstedt, Carl, Skandinav. Arch. f. Physiol., 1929, lvi, 265. Zur Kenntnis der Zufuhr von $\mathrm{P}, \mathrm{Ca}$, und $\mathrm{Mg}$ bei frei gewählter Kost.

25. Van Slyke, Donald D., and Neill, James M., J. Biol. Chem., 1924, lxi, 523. The Determination of Gases in Blood and Other Solutions by Vacuum Extraction and Monometric Measurement. I.

26. $\mathrm{Wu}, \mathrm{H}$., and Ling, S. M., Chinese J. Physiol., 1927, i, 161. Colorimetric Determination of Proteins in Plasma, Cerebrospinal Fluid and Urine. 